\title{
$1 \quad$ Effects of harvesting cell density, medium depth and environmental factors on biomass and lipid 3 productivities of Chlorella vulgaris grown in swine wastewater

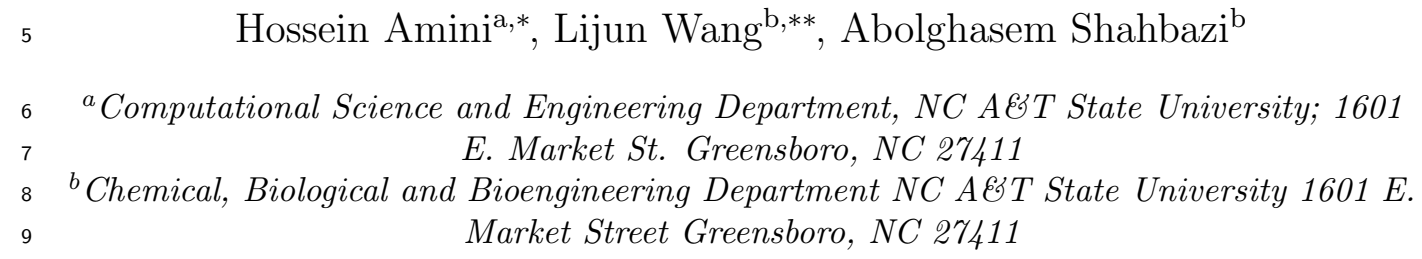

10 Abstract

\footnotetext{
${ }^{*}$ E-mail address: hossein.amini.che@gmail.com
${ }^{* *}$ corresponding author; E-mail address: lwang@ncat.edu

${ }^{*}$ E-mail address: hossein.amini.che@gmail.com
${ }^{* *}$ corresponding author; E-mail address: lwang@ncat.edu

Preprint submitted to Chemical Engineering Science
}

(C) 2016. This manuscript version is made available under the Elsevier user license http://www.elsevier.com/open-access/userlicense/1.0/
June 10, 2016 
21

(ORP) with different medium depths and harvesting cell densities under the weather condition in North Carolina yearly around. At $20 \mathrm{~cm}$ medium depth, the highest growth rate was $0.162 \mathrm{~g} / \mathrm{l} /$ day, which was obtained at $0.1 \mathrm{~g} / \mathrm{l}$ harvesting cell density, $24^{\circ} \mathrm{C}$ and $1,350 \mu \mathrm{Em}^{-2} \mathrm{~s}^{-1}$ solar irradiance in August. If the medium depth increased to $30 \mathrm{~cm}$, the highest growth rate at $0.1 \mathrm{~g} / \mathrm{l}$ harvesting cell density was $0.156 \mathrm{~g} / \mathrm{l} /$ day, which was obtained at $23^{\circ} \mathrm{C}$ and $1,500 \mu \mathrm{Em}^{-2} \mathrm{~s}^{-1}$ in June. If the harvesting cell density increased to $0.4 \mathrm{~g} / \mathrm{l}$, the highest growth rate decreased significantly to 0.033 and $0.02 \mathrm{~g} / \mathrm{l} /$ day for $20 \mathrm{~cm}$ and $30 \mathrm{~cm}$ medium depths, respectively. At $0.1 \mathrm{~g} / \mathrm{l}$ harvesting cell density, the yearly algal productivity was 80 and 59 ton/hectare at $30 \mathrm{~cm}$ and $20 \mathrm{~cm}$ medium depths, respectively. At the average $25 \%$ lipid content of C.vulgaris grown in swine wastewater, the highest lipid yield was 20 and 14.75 ton/hectare/year at $30 \mathrm{~cm}$ and $20 \mathrm{~cm}$ medium depths, respectively. Keywords: Chlorella vulgaris; growth condition optimization; swine wastewater; culture medium depth; open raceway pond; cell density

\section{Introduction}

There is an increasing interest in the growth of microalgae for the production of biofuels such as biodiesel, bioethanol and biohydrogen [1]. It is 
well-established that microalgal-derived biofuels have a potential to make a significant contribution to the US fuel market, due to several unique characteristics inherent to algae [2]. But biofuels from microalgae are not yet feasible because of their high cost [3]. One of the major costs for algal production includes fertilizer and chemical expenses [3]. Algae can be grown in wastewater that may be unfit for crop irrigation or municipal use [4]. Wastewater derived from municipal, agricultural, and industrial activities is a source of nutrients for microalgal cultivation that could significantly reduce the operational costs of algal production systems [5]. Efficient growth of microalgae in wastewater depends on environmental variables and the concentrations of essential nutrients such as $\mathrm{N}$ and $\mathrm{P}[5,6]$. The optimal temperature, light intensity and $\mathrm{pH}$ for maximum algal growth rate vary among algal species $[7,8]$. Deviation from the optimum growth condition subsequently leads to the reduction in biomass yield [8]. Therefore, the microalgal biomass production in wastewater can be increased by optimizing the environmental factors, and manipulating rate-limiting nutrients.

ORPs have been intensively developed since the 1950s in order to provide an industrial-scale solution for microalgal culture [9]. Individual pond areas are up to 1 hectare, with an average depth of 20 to $30 \mathrm{~cm}$ [10]. The biggest 
advantage of these open ponds is their simplicity [1], and compared with conventional mechanical wastewater treatment technologies, open raceways have lower capital and operating costs [11]. However, the growing season is largely dependent on location and, aside from tropical areas, is limited to the warmer months. Bad weather can often stunt algal growth [1]. Energy production in ORPs is a function of several factors that can be classified in three categories: environmental, operational and biological. Besides the environmental conditions, the operating conditions of the medium depth [12] and harvesting cell density $[13,14]$ also significantly affect the algal productivity of an open pond due to their effects on light distribution and utilization $[8,10]$ One strategy to optimize light utilization is to reduce the harvesting culture cell concentration. At large scale, harvesting of $25-33 \%$ of the culture volume may be required daily to keep the operating culture cell concentration at a low level for viable productivity by continuously harvesting algae and adding fresh medium to enhance the light distribution in the medium [8]. Pond depth ranges between 20-30 cm [10], where depths less than $20 \mathrm{~cm}$ increase the head loss and so the energy consumption per unit volume [10, 15], and depths over $30 \mathrm{~cm}$ decrease the production due to light limitations [10]. C.vulgaris has been identified as a potential candidate to be grown in wastew- 
77

92 C.vulgaris(UTEX 2714) was purchased from the UTEX culture collection

\section{Materials and methods}

\subsection{Microalgae cultivation}

\subsubsection{Microalgae and inoculum preparation}

have been conducted on piggery wastewater treatment using microalgae [5]. However, no research was found to analyze the effects of harvesting cell density, medium depth and environmental factors of the growth of C.vulgaris in swine wastewater. The objective of this study was to generate a regression model to predict the maximum growth C.vulgaris and integrate it with a light and heat transfer model to predict the productivity of C.vulgaris in ORPs using swine wastewater at different harvest cell densities, medium depths and environmental conditions. A case study was conducted to use the integrated model to predict the annual algal biomass production in Greensboro, North Carolina, using the weather temperature and the average sunlight intensity for each month during a year.

of algae at the University of Texas at Austin. The algal seed was cultivated using the autoclaved Bold's medium. The seed tubes were incubated in an 
incubated shaker (AlgaeTron AG 130-ECO, Quibit systems Inc, Canada) at a temperature of $24^{\circ} \mathrm{C}$ and light intensity of $100 \mu \mathrm{Em}^{-2} \mathrm{~s}^{-1}$ to prepare the pre-culture as recommended by the supplier.

\subsubsection{Bold's medium and swine wastewater}

For the optimization of the growth environmental condition, the traditional Bold's medium was modified to minimize the effects of nutrients on the algal growth, and to simulate the wastewater nutrient level by increasing the nitrogen concentration from 42 to $100 \mathrm{mg} / \mathrm{l}$. The phosphorus concentration of the Bold's medium was not changed due to its high amount at $53.2 \mathrm{mg} / \mathrm{l}$. The modified Bold's medium was thus composed of $25 \mathrm{mg} / \mathrm{l}$ $\mathrm{CaCl}_{2} \cdot 2 \mathrm{H}_{2} \mathrm{O}, 75 \mathrm{mg} / \mathrm{l} \mathrm{MgSO}_{4} \cdot 7 \mathrm{H}_{2} \mathrm{O}, 610 \mathrm{mg} / 1 \mathrm{NaNO}_{3}$ (250 mg/l originally), $25 \mathrm{mg} / \mathrm{l} \mathrm{NaCl}, 75 \mathrm{mg} / \mathrm{K} \mathrm{K}_{2} \mathrm{HPO}_{4}, 175 \mathrm{mg} / \mathrm{l} \mathrm{KH}_{2} \mathrm{PO}_{4}, 8.82 \mathrm{mg} / 1 \mathrm{ZnSO}_{4} .7 \mathrm{H}_{2} \mathrm{O}$, $1.44 \mathrm{mg} / 1 \mathrm{MnCL}_{2} .4 \mathrm{H}_{2} \mathrm{O}, 0.71 \mathrm{mg} / 1 \mathrm{MoO}_{3}, 1.57 \mathrm{mg} / 1 \mathrm{CuSO}_{4} .5 \mathrm{H}_{2} \mathrm{O}, 0.49 \mathrm{mg} / \mathrm{l}$ $\mathrm{Co}\left(\mathrm{NO}_{3}\right)_{2} \cdot 6 \mathrm{H}_{2} \mathrm{O}, 11.42 \mathrm{mg} / \mathrm{l} \mathrm{H}_{3} \mathrm{BO}_{3}, 50.0 \mathrm{mg} / \mathrm{l} \mathrm{EDTA}, 31.0 \mathrm{mg} / \mathrm{l} \mathrm{KOH}, 4.98$ $\mathrm{mg} / \mathrm{l} \mathrm{FeSO} 4.7 \mathrm{H}_{2} \mathrm{O}$ and $1.0 \mathrm{ml} / \mathrm{l} \mathrm{H}_{2} \mathrm{SO}_{4}$.

Swine wastewater was collected from a lagoon located on the North Carolina A\&T State University's farm in Greensboro, North Carolina. The wastewater was then stored in a refrigerator at $4^{\circ} \mathrm{C}$. During the experiments, the wastewater was filtered to remove solid particles, and autoclaved 
at $121^{\circ} \mathrm{C}$ for $20 \mathrm{~min}$. The nutrients of the wastewater were characterized using a colorimeter (LaMotte SMART3) and given in Table 1. The chemical components of nitrogen and phosphorus in the wastewater were expressed in the forms of ammonia- $\mathrm{N}$, nitrate- $\mathrm{N}$ and phosphate-P. The other components (Fe, $\mathrm{Cu}$ and sulfate) were determined in the previous work [19].

\subsubsection{Experimental design}

$150 \mathrm{ml}$ petri dishes with $1 \mathrm{~cm}$ liquid medium depth were used to culture the algae to generate the regression model that is a function of the growth environmental parameters of temperature, light intensity and $\mathrm{pH}$ value. The petri dishes with a large open surface and shallow depth of the algal medium were used to minimize the effects of gradients of light, temperature, $\mathrm{CO}_{2}$ and $\mathrm{O}_{2}$ on the regression model that may occur in large-scale closed photobioreactors. The sterile dishes were inoculated in a thermostatic incubator at a shaking rate of 50 rounds per minute. A light controller was placed on the top of the shaker-incubator and set at 12 hour:12 hour light/dark cycle for ten days. The 5-level-3-factor central composite design (CCD) given in Table 2 was used to analyze the environmental factors of temperature, light intensity and $\mathrm{pH}$ value on the regression model. The $\mathrm{pH}$ was controlled at a specific value in the range of 6.8-8.0 using the HEPES buffer. HEPES buffer 
was successfully utilized for microalgal culture by several authors [20, 21].

The maximum and minimum levels of each environmental factor were chosen based on the data reported in the literature for temperature $[17,22$, 23], light intensity [24-26] and pH [10]. The DesignExpert (trial version 7.0) was used to design the experiments and analyze the data.

The response of the biomass concentration after 10 days as a function of the environmental factors was approximated by the polynomial quadratic regression model, which was given by:

$$
Y=\beta_{0}+\sum_{i=1}^{k} \beta_{i} x_{i}^{2}+\sum_{i=1}^{k} \beta_{i i} x_{i}^{2}+\sum_{i=1}^{k} \sum_{j=1}^{k} \beta_{i j} x_{i} \beta_{i i} x_{j}+\varepsilon
$$

where $Y$ is the biomass concentration in a 10-day period, $\beta_{0}$ is the offset term, $\beta_{i}$ is the linear effect, $\beta_{i i}$ is the squared effect, $\beta_{i j}$ is the interaction effect, $x_{i}$ is the $i$ th independent variable and $x_{j}$ is the $j$ th independent variable [27].

\subsubsection{Cultivation of C.vulgaris in swine wastewater}

The nitrogen concentration of swine wastewater was as the same level as the modified Bold's medium used for the optimization experiments. The swine wastewater also had a high phosphorus content. Thus, it was assumed that the regression model obtained using the experimental data collected in 
the modified Bold's medium could be modified with a correction factor and used for estimating the algal production rate in swine wastewater.

C.vulgaris was grown in the wastewater and modified Bold's medium at the optimum environmental conditions, using a tubular bioreactor including eight tubes, each $2.5 \mathrm{~cm}$ in diameter and $80 \mathrm{ml}$ in volume(Z160 MultiCultivator, Qubit systems). The optimum condition which was determined by RSM included light intensity at $240 \mu \mathrm{Em}^{-2} \mathrm{~s}^{-1}$, temperature at $24^{\circ} \mathrm{C}$ and $\mathrm{pH}$ at 7.4 which was controlled by injecting $\mathrm{CO}_{2}$ once a day. The biomass concentration of C.vulgaris in the Bold's medium and the swine wastewater after 10 days were then compared to determine a correction factor for the regression model to predict the algal growth in swine wastewater. This factor was obtained by dividing the biomass yield produced in the swine wastewater by the biomass concentration in the Bold's medium.

2.1.5. Analysis of nutrients in growth media and measurement of biomass concentration and lipid content

Samples were taken from the growing medium and centrifuged at an acceleration of $36 \mathrm{~g}$ for 10 minutes to separate the algal cells from the liquid medium. The concentrations of $\mathrm{NH}_{3}-\mathrm{N}, \mathrm{NO}_{3}-\mathrm{N}$ and $\mathrm{PO}_{4}-\mathrm{P}$ in the liquid medium, which were considered as the main forms of nitrogen and phospho- 
rus to be assimilated by algal cells, were then measured using a colorimeter (LaMotte Smart3, Lammotte company, Chestertown, MD, USA).

After the stationary phase was observed, the biomass was separated from the medium by centrifuging under $36 \mathrm{~g}$ acceleration and $25^{\circ} \mathrm{C}$ for 10 minutes. To measure the dry weight of algal biomass, the wastewater was dumped from the top of the centrifuged samples. The biomass was then sucked up using a $1000 \mu l$ micro pipet and dried at $50^{\circ} \mathrm{C}$ in an incubator over night. Biomass dry weight was calculated by subtracting the total mass of dishes with dry biomass and the mass of empty dishes. Lipid content of the dry algal biomass was then measured using the traditional Bligh and Dyer method [28].

\subsection{Mathematical modeling of the light and temperature distribution in algal culture medium at different cell densities and medium depth}

There is a large variation in the local growth condition in a large ORP. The light transfer in a culture medium generates a gradient of light intensity in the culture medium, which decreases from the surface irradiance with the increase of the medium depth and algal cell concentration. The medium temperature in an ORP is usually different from the temperature of surrounding air, which is caused by the solar radiative heat absorbed by the medium heat loss due to water evaporation from the pond, heat loss from the pond 
wall and convective heat exchange between medium and air. Therefore, it is necessary to develop an integrated regression model, light transfer and heat exchange model to predict the algal productivity in an ORP.

\subsubsection{Modeling of light distribution in growth medium}

The solar irradiance data set provided by National Renewable Energy

Laboratory (NREL) (Figure 1a), represents the light intensity only on the surface of the medium. The light intensity decreases through the medium depth because of the absorption by the microalgae cells. Thus, the light intensity would be lower at deeper levels of the medium in the open pond's channels.

Two of the major factors that must be considered in estimation of the algal biomass production using ORPs, are the medium depth and the harvesting cell density, which affect the light distribution in the open ponds. The delivery and the distribution of the light into the culture medium can be calculated using Beer-Lambert's law (Equation 2), which was usually used to estimate local light intensity within a culture medium [29]:

$$
I=I_{0} e^{-\left(k_{c} c+k_{m}\right) z}
$$


214 ${ }_{218}\left(z_{n}-z_{n-1}\right)$.

where $I$ is the light intensity at a given depth of $z, I_{0}$ is the light intensity at the culture surface, $c$ is the cell density, $k_{c}$ is the extinction coefficients for algae cells suspended in swine wastewater, and $k_{m}$ is the medium extinction coefficient. $k_{c}$ and $k_{m}$ were measured at 2.0 and $0.081 \mathrm{~cm}^{-1} \mathrm{~g}^{-1}$ respectively, using a spectrophotometer for C.vulgaris suspended in the swine wastewater. The average light intensity in the microalgal medium in each divided zone along the medium depth was used to calculate the algal growth rate in each divided zone. This method takes into account the shading effects of microalgae cells in ORP's channels. According to Equation 2, the average light intensity in a culture medium with a given cell concentration and a given medium depth can be calculated by [30]:

$$
\begin{aligned}
\bar{I}_{n} & =\frac{1}{\Delta z} \int_{z_{n-1}}^{z_{n}} I_{n-1} e^{-\left(k_{c} c+k_{m}\right) z} d z \\
& =\frac{I_{n-1}-I_{n}}{\ln I_{n-1}-\ln I_{n}}
\end{aligned}
$$

where $\bar{I}_{n}$ is the average light intensity at zone $n$, and $\Delta z$ is the zone height 
233

\subsubsection{Modeling of temperature distribution in growth medium}

As a ORP for algal cultivation is usually a shallow pond, it was assumed that there was no temperature gradient in the culture medium. The pond wall was assumed to be well insulated and the heat loss through the pond wall, $Q_{w}$ was thus zero. Effects of radiation, evaporation and convection on the medium temperature were analyzed by the heat balance equation of the culture medium in an ORP, which can be expressed as:

$$
\rho c_{p} A X \frac{d T}{d t}=Q_{r}-Q_{c}-Q_{e}-Q_{w}
$$

where $\rho$ is the density $\left(\mathrm{kg} / \mathrm{m}^{3}\right), c_{p}$ is the heat capacity $(\mathrm{J} / \mathrm{kg} \mathrm{K}), A$ is the area size of the pond $\left(m^{2}\right), X$ is the depth of the pond $(m), T$ is temperature $\left({ }^{\circ} \mathrm{C}\right), t$ is time $(s), Q_{r}$ is the net solar radiation that is absorbed by the medium $(W)$ which is the difference between the incident solar radiation on the pond's surface, $Q_{\text {rin }}$ and the solar radiation which comes out of the pond, $Q_{\text {rout }}:$

$$
Q_{r}=Q_{\text {rin }}-Q_{\text {rout }}
$$

$Q_{c}$ is the convective heat loss from the surface $(W), Q_{e}$ is the evaporative heat loss from the surface $(W)$, and $Q_{w}$ is the heat loss through walls of the 
pond $(W)$.

The fractions of solar radiation on the surface that reaches the depth of $x$ in water is given as [31]:

$$
h_{x}=H(0.36-0.08 \ln x)
$$

where $x$ is the thickness of water layer in meters, $h_{x}$ is the solar radiation in any depth of water $\left(W / m^{2}\right)$, and $H$ is the solar radiation on the surface $\left(W / m^{2}\right)$. Equation 6 is valid from 0.01 to $10 \mathrm{~m}$ water depth. Therefore, the amount of solar radiation that is absorbed at a given medium depth can be calculated by:

$$
Q_{\text {rin }}=H A(1-0.36+0.08 \ln x)
$$

where $x$ is the depth of pond.

Radiation heat loss on the surface can be calculated as:

$$
Q_{\text {rout }}=\sigma \in A\left(T^{4}-T_{k}^{4}\right)
$$


251

252

253 254 by:

255 256 257 258

259 260

261 $264(k J / k g \cdot K)$.

259

$$
T_{k}=0.0552 T_{a}^{1.5}
$$

The convective heat exchange between the medium and air was determined

$Q_{c}=h_{c} A\left[T-T_{a}\right]$

In equation $10, h_{c}$ is the heat transfer coefficient from the water surface to the air $\left(W / m^{2}\right)$ which was calculated as a fraction of the monthly average wind speed, $v(\mathrm{~m} / \mathrm{s})$ :

$$
h_{c}=5.7+3.8 v
$$

The heat loss from the surface by water evaporation $\left(Q_{e}\right)$ was given by:

$$
Q_{e}=\left(\frac{\lambda h_{c}\left(p-p_{a}\right)}{1.6 C_{s} p_{a t m}}\right) A
$$

where $\lambda$ is the latent heat of vaporization $\left(334 \mathrm{~kJ} / \mathrm{kg}\right.$ for water), $h_{c}$ is the convective heat transfer to water, and $C_{s}$ is the humid heat capacity of air 
The humid heat capacity of air was determined by:

$$
C_{s}=1.005+1.82 \gamma_{h}
$$

where $\gamma_{h}$ is the relative humidity (Figure 1c).

The saturated water vapor pressure at the water temperature, $p(m m \mathrm{Hg})$, was calculated as:

$$
p=\exp [18.403-3885 /(T+230)]
$$

The partial pressure of water vapor in the ambient air, $p_{a}(m m \mathrm{Hg})$, was calculated as:

$$
p_{a}=\gamma_{h} \exp \left[18.403-3885 /\left(T_{a}+230\right)\right]
$$

where the unit of temperature was in ${ }^{\circ} \mathrm{C}$.

The heat balance equation (Equation 4), was solved using a MATLAB code. The density and specific heat capacity of the culture medium were assumed to be constant at $\rho=1000 \mathrm{~kg} / \mathrm{m}^{3}$ and $c_{p}=4180 \mathrm{~J} / \mathrm{kgK}$ for water. It was assumed that there was no change in medium depth, $X$, during algal cultivation. The heat balance analysis was conducted for an ORP with a 
280

surface area of 1 hectare $\left(A=1\right.$ hectare $\left.=10000 \mathrm{~m}^{2}\right)$.

\subsection{Calculation of algal production rate in an ORP}

It was assumed that the microalgal medium was well mixed, so the effects of cell distribution on local light intensity at a given medium level was neglected. The culture medium in an ORP was divided into $N$ zones along the medium depth. The local algal biomass concentration in each zone was then calculated by the regression model equation (generated from Equation 1) using the local light intensity calculated by Equation 3, and the medium temperature calculated by Equation 4. The total algal biomass concentration will be the average of sum of the algal biomass concentration for a ten day period in each divided zone, which was expressed as:

$$
Y=\frac{\sum_{n=1}^{N} Y_{n}}{N}
$$

where $Y_{n}$ is the local biomass concentration at zone $n$. 
2.4. Estimation of algal biomass and lipid productivity in North Carolina using the integrated regression model, light transfer and heat transfer model

The regression model was integrated with the light and heat transfer models to estimate the potential of growing algae on swine wastewater in ORPs in North Carolina yearly around. Solar irradiance and temperature determine the length of the growing period and directly affect algae productivity in a specific region. Figure $1 \mathrm{a}$ and $1 \mathrm{~b}$ show the monthly surface sunlight intensity and temperature in Greensboro, North Carolina, respectively, which were reported by NREL [32].

The monthly average solar irradiation, $I_{0}$, and temperature, $T_{a}$, in Greensboro, North Carolina were used as the boundary conditions of the light transfer and heat transfer models to calculate the light intensity and temperature profiles in the growth medium at different harvesting cell densities and depths, respectively. These light intensity and temperature profiles were further used in the regression model to calculate the monthly algal biomass productivity. The $\mathrm{pH}$ value in the regression model was kept at its optimum value of 7.4 , determined by the kinetic model.

The potential of algal biomass production in an ORP with two culture 
depths of 20 and $30 \mathrm{~cm}$ has been estimated. Four different harvesting cell concentrations of $0.1,0.2,0.3$ and $0.4 \mathrm{~g} / 1$ were used to estimate the annual biomass production using swine wastewater as the culture medium.

\section{Results and discussion}

\subsection{Growth regression model and optimum growth conditions}

Table 3 shows the experimental conditions, and the predicted and experimental responses. Table 4 gives the the results of the Analysis of Variance (ANOVA) for the regression. The regression model is significant with the $F$ value of 162.11 and the $P$-value of $<0.0001$. The $R^{2}$ is 0.9932 , which implies this response model could explain $99.32 \%$ of the variability. Equation 17 is the generated regression model obtained with RSM analysis: The average algal biomass production rate was calculated as:

$$
Y(g / l / d)=Y / t \quad t=10 \text { days }
$$




\subsubsection{Light intensity}

Figures $2 \mathrm{a}, 2 \mathrm{~b}$ show the effect of light intensity on the algal biomass production. As it can be seen, the biomass concentration in a 10-day culture period, increased with the light intensity to a maximum value and then decreased with the further increase of light intensity. Therefore, there is an optimum light intensity for algal growth, which has been confirmed by the well-known Photosynthesis-Irradiance (P-I) curve for analyzing the response of photosynthetically grown cells to light [33]. According to the P-I curve, cell growth increases with light intensity in the light limited region and then decreases with the further increase of the light intensity in the photoinhibited region [33]. The optimum light intensity for C.vulgaris which was determined by the regression model was $240 \mu E \cdot m^{-2} s^{-1}$. This value is close to the value previously reported in the literature [34]. Eliminating the effects of self shading of microalgae cells due to shallow culture medium depth used in the experiments, resulted in a maximum light intensity of $400 \mu E \cdot \mathrm{m}^{-2} \mathrm{~s}^{-1}$. Therefore, the regression model is an independent function of local microalgae cell positions, thus the shading effects, and depends on the local average light intensity at different culture medium depths in the pond's channels. 


\subsubsection{Temperature}

The effects of temperature on the algal biomass production is presented in Figures 2c, 2d. The algal biomass production decreased with very low and high temperatures. As the increase of temperature generally accelerates the metabolic rate of microalgae, very low temperature could inhibit the algal growth. However, $\mathrm{CO}_{2}$ solubility in water decreases with the temperature, thus decreasing the algal growth rate. Therefore, it is very important to keep the temperature close to an optimum value. The optimum temperature for C.vulgaris that was determined by the regression model was $24^{\circ} \mathrm{C}$.

\subsection{3. $p H$}

Figures 2e, $2 \mathrm{f}$ show the effect of $\mathrm{pH}$ on the algal biomass production. It can be seen that the algal biomass production was very low at a very low or high $\mathrm{pH}$ value. As the $\mathrm{pH}$ value of algal medium tends to increase during the light period, the injection of a proper amount of $\mathrm{CO}_{2}$ into the algal medium decreases the $\mathrm{pH}$ back to the optimum level, as well as increasing the carbon supply, which leads to an increase in the algal biomass production. The optimum $\mathrm{pH}$ value for C.vulgaris was determined at 7.4 by the regression model. 


\subsection{Cultivation of C.vulgaris in swine wastewater}

C.vulgaris was grown in swine wastewater at the optimum environmental condition. The optimum condition was previously determined at the temperature of $24^{\circ} \mathrm{C}$, light intensity of $240 \mu \mathrm{Em}^{-2} s^{-1}$ and $\mathrm{pH}$ value of 7.4. Cultivations were stopped after a 10-day period as there was no further increase in the algal biomass. The biomass production obtained in swine wastewater was then compared to the algal growth results in the Bold's and modified Bold's medium, obtained at the optimum growth condition.

\subsubsection{Biomass concentration}

Figure 3 shows the biomass production of C.vulgaris growth in different microalgal media. The microalgae grown in swine wastewater with $102 \mathrm{mg} / \mathrm{l}$ nitrogen and $76 \mathrm{mg} / \mathrm{l}$ phosphorus at the optimum condition for 10 days achieved its highest biomass production at $1.6 \mathrm{~g} / \mathrm{l}$. The biomass production of the algae grown in the Bold's medium with $42 \mathrm{mg} / \mathrm{l}$ nitrogen and $53 \mathrm{mg} / \mathrm{l}$ phosphorus was $0.86 \mathrm{~g} / \mathrm{l}$, whilst the biomass production in the modified Bold's medium with $100 \mathrm{mg} / \mathrm{l}$ nitrogen and $53 \mathrm{mg} / \mathrm{l}$ phosphorus at the optimum condition was $1.91 \mathrm{~g} / \mathrm{l}$. Therefore, at the optimum environmental condition, the biomass production obtained in the swine wastewater was $84 \%$ 
of that obtained in modified Bold's medium which had similar amounts of $\mathrm{N}$ and P. A correction factor of 0.84 was then used to modify the regression model so that the modified regression model can be used to predict the growth of C.vulgaris in swine wastewater at different environmental conditions. The decrease of the growth rate in the swine wastewater at the nutrient levels as modified Bold's medium might be caused by the turbidity of the wastewater that decreased the light intensity, the absence of some micronutrients, and the presence of some algal growth inhibitors.

\subsubsection{Nutrient removal}

The final nutrient concentrations in terms of nitrate-nitrogen $\left(\mathrm{NO}_{3}-\mathrm{N}\right)$ and phosphate-phosphorous $\left(\mathrm{PO}_{4}-\mathrm{P}\right)$ were analyzed after the cultivation was stopped. C.vulgaris could remove $99.6 \%$ of nitrogen and $32.6 \%$ of phosphorus in the swine wastewater at the optimum growth condition after 10-day growth. Therefore, C.vulgaris can significantly utilize the nutrients in the swine wastewater. The swine wastewater had a large excess amount of phosphorus that was needed by the algae. 


\subsection{Temperature distribution in pond}

Figure 4 shows the profiles of medium average temperature in a pond operating at the annual weather condition given in Figure 1. The difference between the ambient and medium temperatures steadily increases from $0^{\circ} \mathrm{C}$ in January to $3^{\circ} \mathrm{C}$ in July and decreases to $0^{\circ} \mathrm{C}$ in December.

\subsection{Estimation of algal biomass and lipid productivities in North Carolina} The algal biomass and lipid productivities in North Carolina were calculated based on a continuous culture with harvesting cell densities of $0.1,0.2$, 0.3 and $0.4 \mathrm{~g} / \mathrm{l}$, for two different culture depths of 20 and $30 \mathrm{~cm}$.

\subsubsection{Biomass productivity}

As seen in Figures 5a to 5d, the growth rate on a volume basis increases with the increase of light intensity and temperature in the culture medium. The mean light intensity in the growth medium will increase with the decrease of the medium depth and harvesting cell density at a given solar irradiation. The local temperature and light intensity in May, June and July, as shown in Figures $1 \mathrm{~b}$ and $1 \mathrm{a}$, are close to the optimum environmental growth conditions for C.vulgaris $\left(240 \mu \mathrm{Em}^{-2} \mathrm{~s}^{-1}, 24^{\circ} \mathrm{C}\right.$ and $\mathrm{pH}$ of 7.4$)$. As it can be seen in Figure 5a, the growth rate between November to February is close to zero for 
the harvesting cell density of $0.1 \mathrm{~g} / \mathrm{l}$. However the number of months with negligible growth increased with the increase of the harvesting cell density. As it can be seen from Figure 5d, at the harvesting cell density of $0.4 \mathrm{~g} / \mathrm{l}$, the growth was close to zero from October to March. The highest production rates were $0.162 \mathrm{~g} / \mathrm{l} /$ day for $20 \mathrm{~cm}$ and $0.156 \mathrm{~g} / \mathrm{l} /$ day for $30 \mathrm{~cm}$ medium depths obtained at $0.1 \mathrm{~g} / 1$ harvesting cell density in May-September $\left(23-25^{\circ} \mathrm{C}\right.$ and 1400-1500 $\left.\mu \mathrm{Em}^{-2} \mathrm{~s}^{-1}\right)$, compared to $0.058 \mathrm{~g} / \mathrm{l} /$ day for $20 \mathrm{~cm}$ and $0.02 \mathrm{~g} / \mathrm{l} /$ day for $30 \mathrm{~cm}$ at $0.4 \mathrm{~g} / \mathrm{l}$ harvesting cell density.

The growth rate on a surface area basis can be calculated by multiplying the productivity on a volume basis by medium depth. At the $0.1 \mathrm{~g} / \mathrm{l}$ harvesting cell density, the growth rate on a surface area basis in the open pond with $30 \mathrm{~cm}$ depth was 85 ton/hectare/year, which was higher than 65 ton/hectare/year for the $20 \mathrm{~cm}$ depth. By increasing the harvesting cell density to $0.4 \mathrm{~g} / \mathrm{l}$, the growth rate on a surface area basis in the open pond with $20 \mathrm{~cm}$ depth was 14 ton/hectare/year, which was higher than 5 ton/hectare/year for the $30 \mathrm{~cm}$ depth.

Figure 6 shows the monthly biomass yield for one hectare surface area, at both 20 and $30 \mathrm{~cm}$ medium depths. The highest monthly biomass yield in the open pond with the $30 \mathrm{~cm}$ medium depth was 14.1 ton/hectare ob- 
tained at $0.1 \mathrm{~g} / \mathrm{l}$ harvesting cell density in June-August, which was higher than 9.6 ton/hectare for the $20 \mathrm{~cm}$ medium depth. Without manipulating the growth environmental conditions, the yearly biomass yields for one hectare surface area were 59 tons for $20 \mathrm{~cm}$ and 80 tons for $30 \mathrm{~cm}$ medium depths. The major challenge in designing a microalgal production plant in this region is the high variation in light irradiance and temperature between summer and winter. Since swine wastewater can provide sufficient nutrients through fedbatch operation, low light intensity and temperature are the two barriers to achieve high algal biomass production from November to February.

\subsubsection{Lipid production}

An average total lipid content of $25 \%$ were used to calculate the total lipid production for C.vulgaris grown in swine wastewater. Similar values have been reported for small scale systems by other authors [35]. In this work, it was assumed that the value of $25 \%$ is valid for all the growth conditions yearly around. Based on these data, the highest lipid yield is obtained for the system with the harvesting cell concentration of $0.1 \mathrm{~g} / 1$ and the medium depth of $30 \mathrm{~cm}$ which was calculated at 20 ton/hectare/year (out of 80 ton/hectare/year biomass). The lipid yield for the same condition for the system with a medium depth of $20 \mathrm{~cm}$ is calculated at 14.75 ton/hectare/year 
455

(out of 59 ton/hectare/year biomass).

\section{Conclusion}

The main environmental growth factors including temperature, light intensity and $\mathrm{pH}$ for $C$.vulgaris were analyzed by utilizing RSM. The optimum growth condition was found at $240 \mu \mathrm{Em}^{-2} \mathrm{~s}^{-1}, 24^{\circ} \mathrm{C}$ and $\mathrm{pH}$ of 7.4 , using the modified Bold's medium with $100 \mathrm{mg} / \mathrm{l}$ nitrogen and $53 \mathrm{mg} / \mathrm{l}$ phosphorus. The experimental data were used to generate a regression model with a $R^{2}$ of 0.9932 for the predict the biomass productivity as a function of growth environmental condition. The microalgae grown in swine wastewater with $102 \mathrm{mg} / \mathrm{l}$ nitrogen and $76 \mathrm{mg} / \mathrm{l}$ phosphorus at the optimum condition achieved the average growth rate at $0.160 \mathrm{~g} / \mathrm{l} /$ day, compared to $0.191 \mathrm{~g} / \mathrm{l} /$ day for the of the algae grown in the modified Bold's medium with $100 \mathrm{mg} / \mathrm{l}$ nitrogen and $53 \mathrm{mg} / \mathrm{l}$ phosphorus at the same condition. Therefore, a correction factor of 0.84 , which was the ratio of $0.160 \mathrm{~g} / \mathrm{l} /$ day and $0.191 \mathrm{~g} / \mathrm{l} /$ day growth rates of the algae in swine wastewater and modified Bolds medium at the optimum environmental condition, respectively, was used in the regression model that was integrated with a light and heat transfer model to estimate the algal productivity in swine wastewater. In an ORP, the growth rate 
on a volume basis increased with the increase of light intensity and temperature in the culture medium. The mean light intensity in the growth medium also increased with the decrease of the medium depth and harvesting cell density at a given solar irradiation. The highest production rates were $0.162 \mathrm{~g} / \mathrm{l} /$ day for $20 \mathrm{~cm}$ and $0.156 \mathrm{~g} / \mathrm{l} /$ day for $30 \mathrm{~cm}$ medium depths obtained at $0.1 \mathrm{~g} / \mathrm{l}$ harvesting cell density in North Carolina in Summer with a temperature from $23-25^{\circ} \mathrm{C}$ and solar irradiance of $1400-1500 \mu \mathrm{Em}^{-2} \mathrm{~s}^{-1}$. However, if the harvesting cell density increased to $0.4 \mathrm{~g} / \mathrm{l}$, the highest production rates decreased to $0.058 \mathrm{~g} / \mathrm{l} /$ day for the $20 \mathrm{~cm}$ medium depth and $0.02 \mathrm{~g} / \mathrm{l} /$ day for $30 \mathrm{~cm}$ medium depth at the same location. The algal productivity was 80 ton/hectare/year in the open pond with $30 \mathrm{~cm}$ medium depth, which was higher than 59 ton/hectare/year for the open pond with $20 \mathrm{~cm}$ depth. At the harvesting cell density of $0.4 \mathrm{~g} / \mathrm{l}$, the annual algal biomass productivities were only $14 \mathrm{ton} /$ hectare/year for the $20 \mathrm{~cm}$ medium depth, which was higher than 5 ton/hectare/year for the $30 \mathrm{~cm}$ depth. By assuming a $25 \%$ lipid content in C.vulgaris biomass, the highest lipid productivities were 20 ton/hectare/year and 4.75 ton/hectare/year for the medium depths of $30 \mathrm{~cm}$ and $20 \mathrm{~cm}$ at the harvesting cell density of $0.1 \mathrm{~g} / 1$, respectively. 


\section{Acknowledgments}

A contribution of North Carolina Agricultural and Technical State University, supported by funds fully provided by U.S. Department of Agriculture (USDA NIFA awards: 2013-38821-21141 and NC.X-294-5-15-130-1). Mention of a trade name, proprietary products, or company name is for presentation clarity and does not imply endorsement by the authors or the university.

\section{References}

[1] J. Singh and S. Gu, "Commercialization potential of microalgae for biofuels production," Renewable and Sustainable Energy Reviews, vol. 14, no. 9 , pp. 2596-2610, 2010.

[2] R. Davis, A. Aden, and P. T. Pienkos, "Techno-economic analysis of autotrophic microalgae for fuel production," Applied Energy, vol. 88, no. 10, pp. 3524-3531, 2011.

[3] A. Mehrabadi, R. Craggs, and M. Farid, "Wastewater treatment high rate algal ponds (wwt hrap) for low-cost biofuel production," Bioresource technology, 2014. 
[4] K. Sander and G. Murthy, "Life cycle analysis of algae biodiesel," The International Journal of Life Cycle Assessment, vol. 15, no. 7, pp. 704714, 2010.

[5] R. A. Abou-Shanab, M.-K. Ji, H.-C. Kim, K.-J. Paeng, and B.-H. Jeon, "Microalgal species growing on piggery wastewater as a valuable candidate for nutrient removal and biodiesel production," Journal of Environmental Management, vol. 115, no. 0, pp. 257 - 264, 2013.

[6] J. K. Pittman, A. P. Dean, and O. Osundeko, "The potential of sustainable algal biofuel production using wastewater resources," Bioresource Technology, vol. 102, no. 1, pp. 17 - 25, 2011. Special Issue: Biofuels II: Algal Biofuels and Microbial Fuel Cells.

[7] J. Park, R. Craggs, and A. Shilton, "Wastewater treatment high rate algal ponds for biofuel production," Bioresource Technology, vol. 102, no. 1, pp. 35 - 42, 2011. Special Issue: Biofuels - II: Algal Biofuels and Microbial Fuel Cells.

[8] I. Rawat, R. R. Kumar, T. Mutanda, and F. Bux, "Biodiesel from microalgae: A critical evaluation from laboratory to large scale production," Applied Energy, vol. 103, pp. 444-467, 2013. 
[9] W. Farooq, W. I. Suh, M. S. Park, and J.-W. Yang, "Water use and its recycling in microalgae cultivation for biofuel application," Bioresource technology, 2014.

[10] R. A. Andersen, Algal culturing techniques. Academic press, 2005.

[11] H. E. Muga and J. R. Mihelcic, "Sustainability of wastewater treatment technologies," Journal of environmental management, vol. 88, no. 3, pp. $437-447,2008$.

[12] Park, Stephen and Li, Yebo, "Integration of biological kinetics and computational fluid dynamics to model the growth of Nannochloropsis salina in an open channel raceway," Biotechnology and bioengineering, vol. 112, no. 5, pp. 923-933, 2015.

[13] Logan Christenson and Ronald Sims, "Production and harvesting of microalgae for wastewater treatment, biofuels, and bioproducts," Biotechnology Advances, vol. 29, no. 6, pp. 686 - 702, 2011.

[14] J.B.K. Park and R.J. Craggs and A.N. Shilton, "Enhancing biomass energy yield from pilot-scale high rate algal ponds with recycling," Water Research, vol. 47, no. 13, pp. 4422 - 4432, 2013. 
[15] Norsker, Niels-Henrik and Barbosa, Maria J and Vermuë, Marian H and Wijffels, René H, "Microalgal production - a close look at the economics," Biotechnology Advances, vol. 29, no. 1, pp. 24-27, 2011.

[16] A. Packer, Y. Li, T. Andersen, Q. Hu, Y. Kuang, and M. Sommerfeld, "Growth and neutral lipid synthesis in green microalgae: A mathematical model," Bioresource Technology, vol. 102, no. 1, pp. 111-117, 2011.

[17] T. Xie, Y. Sun, K. Du, B. Liang, R. Cheng, and Y. Zhang, "Optimization of heterotrophic cultivation of chlorella sp. for oil production," Bioresource Technology, vol. 118, no. 0, pp. 235 - 242, 2012.

[18] A. Ruiz-Marin, L. G. Mendoza-Espinosa, and T. Stephenson, "Growth and nutrient removal in free and immobilized green algae in batch and semi-continuous cultures treating real wastewater," Bioresource Technology, vol. 101, no. 1, pp. 58 - 64, 2010.

[19] B. Zhang, L. Wang, R. Hasan, and A. Shahbazi, "Characterization of a native algae species chlamydomonas debaryana: Strain selection, bioremediation ability, and lipid characterization," BioResources, vol. 9, no. 4, pp. 6130-6140, 2014.

[20] J. Stauber and T. Florence, "Mechanism of toxicity of ionic copper and 
copper complexes to algae," Marine biology, vol. 94, no. 4, pp. 511-519, 1987.

[21] G. McFadden and M. Melconian, "Use of hepes buffer for microalgal culture media and fixation for elecron microscopy," Phcologia, vol. 25, no. 4, pp. 551-557, 1986.

[22] S.-Y. Chen, L.-Y. Pan, M.-J. Hong, and A.-C. Lee, "The effects of temperature on the growth of and ammonia uptake by marine microalgae.," Botanical Studies, vol. 53, no. 1, 2012.

[23] S. H. CHO, S.-C. JI, S. B. HUR, J. BAE, I.-S. PARK, and Y.-C. SONG, "Optimum temperature and salinity conditions for growth of green algae chlorella ellipsoidea and nannochloris oculata," Fisheries Science, vol. 73, no. 5, pp. 1050-1056, 2007.

[24] B. Cheirsilp and S. Torpee, "Enhanced growth and lipid production of microalgae under mixotrophic culture condition: Effect of light intensity, glucose concentration and fed-batch cultivation," Bioresource Technology, vol. 110, no. 0, pp. $510-516,2012$.

[25] A. Solovchenko, I. Khozin-Goldberg, S. Didi-Cohen, Z. Cohen, and M. Merzlyak, "Effects of light intensity and nitrogen starvation on 
growth, total fatty acids and arachidonic acid in the green microalga parietochloris incisa," Journal of Applied Phycology, vol. 20, no. 3, pp. 245-251, 2008.

[26] C. Yeesang and B. Cheirsilp, "Effect of nitrogen, salt, and iron content in the growth medium and light intensity on lipid production by microalgae isolated from freshwater sources in thailand," Bioresource Technology, vol. 102, no. 3, pp. $3034-3040,2011$.

[27] M. Azma, M. S. Mohamed, R. Mohamad, R. A. Rahim, and A. B. Ariff, "Improvement of medium composition for heterotrophic cultivation of green microalgae, tetraselmis suecica, using response surface methodology," Biochemical Engineering Journal, vol. 53, no. 2, pp. 187 - 195, 2011.

[28] E. G. Bligh and W. J. Dyer, "A rapid method of total lipid extraction and purification," Canadian journal of biochemistry and physiology, vol. 37, no. 8, pp. 911-917, 1959.

[29] C.-G. Lee, "Calculation of light penetration depth in photobioreactors," Biotechnology and Bioprocess Engineering, vol. 4, no. 1, pp. 78-81, 1999.

[30] X. Wu and J. C. Merchuk, "A model integrating fluid dynamics in photo- 
synthesis and photoinhibition processes," Chemical Engineering Science, vol. 56, no. 11, pp. $3527-3538,2001$.

[31] A. H. Sayer, H. Al-Hussaini, and A. N. Campbell, "New theoretical modelling of heat transfer in solar ponds," Solar Energy, vol. 125, pp. 207 $-218,2016$.

[32] NREL, "30-year average of monthly solar radiation," 1961-1990. [Online; accessed 03 September 2015].

[33] Q. Bechet, A. Shilton, and B. Guieysse, "Modeling the effects of light and temperature on algae growth: State of the art and critical assessment for productivity prediction during outdoor cultivation," Biotechnology Advances, vol. 31, no. 8, pp. 1648 - 1663, 2013.

[34] A. Dauta, J. Devaux, F. Piquemal, and L. Boumnich, "Growth rate of four freshwater algae in relation to light and temperature," Hydrobiologia, vol. 207, no. 1, pp. 221-226, 1990.

[35] T. J. Lundquist, I. C. Woertz, N. Quinn, and J. R. Benemann, "A realistic technology and engineering assessment of algae biofuel production," Energy Biosciences Institute, p. 1, 2010. 
${ }_{613}$ List of figures:

Figure 1 The annual weather data in Greensboro, North Carolina; (a) Average monthly solar irradiance $\left(\mu E m^{-2} s^{-1}\right)$ (Reported by NREL); (b)Average daily temperature for each month $\left({ }^{\circ} \mathrm{C}\right)$ (Reported by NREL); (c) Average relative humidity yearly around, reported by University of North Carolina at Chapel Hill (UNC Chapel Hill); (d) Average annually wind speed (Reported by UNC Chapel Hill) Figure ?? Biomass production as a function of environmental growth parameters Figure 3 Algal biomass production in different media over a 10-day growth period at the optimum environmental growth condition

Figure 4 Comparison of average daily ambient temperature and medium temperature $\left({ }^{\circ} \mathrm{C}\right)$

Figure 5 The growth rate of C.vulgaris in swine wastewater

Figure 6 Monthly productivity for one hectare surface area 


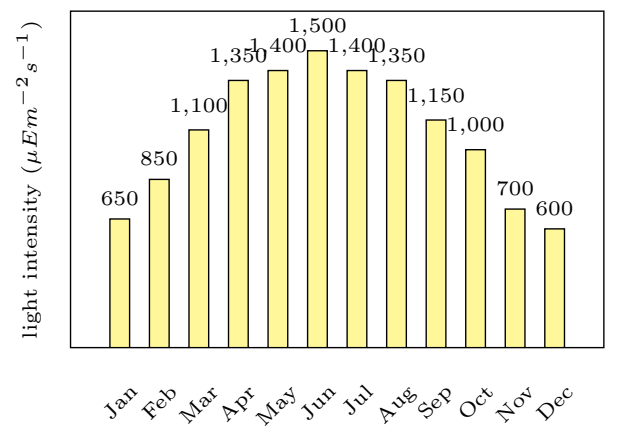

(a)

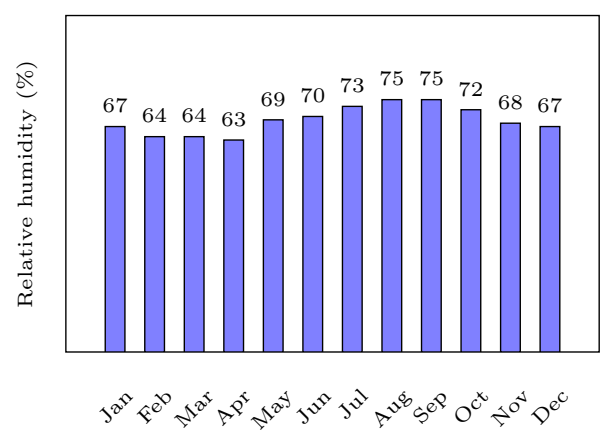

(c)

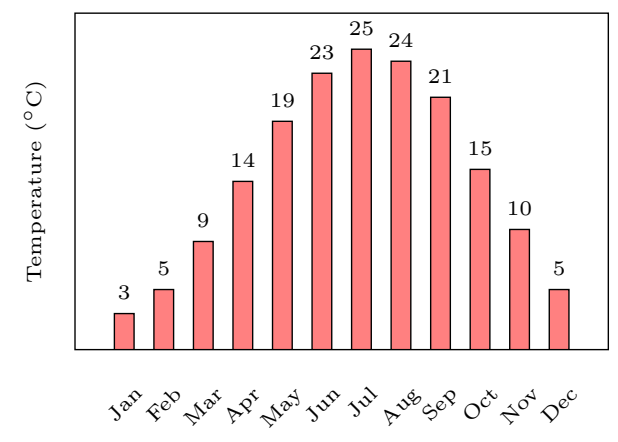

(b)

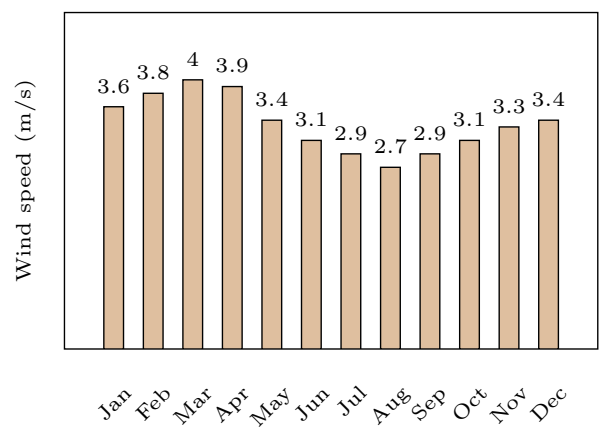

(d)

Figure 1: The annual weather data in Greensboro, North Carolina; (a) Average monthly solar irradiance $\left(\mu E m^{-2} s^{-1}\right)$ (Reported by NREL); (b)Average daily temperature for each month $\left({ }^{\circ} \mathrm{C}\right)$ (Reported by NREL); (c) Average relative humidity yearly around, reported by University of North Carolina at Chapel Hill (UNC Chapel Hill); (d) Average annually wind speed (Reported by UNC Chapel Hill) 


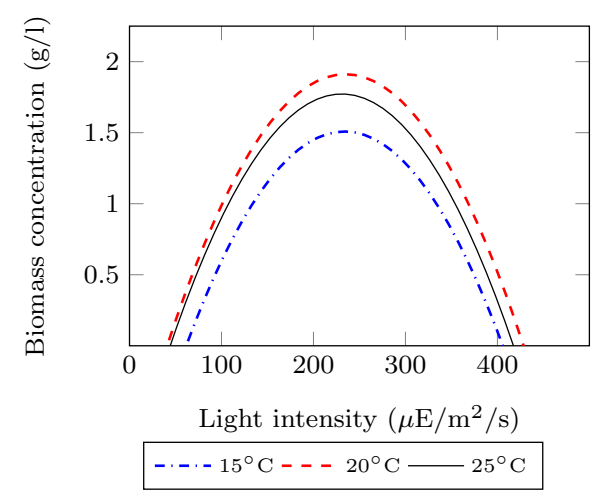

(a) Biomass concentration as a function of light intensity and temperature at $\mathrm{pH}$ of 7.4

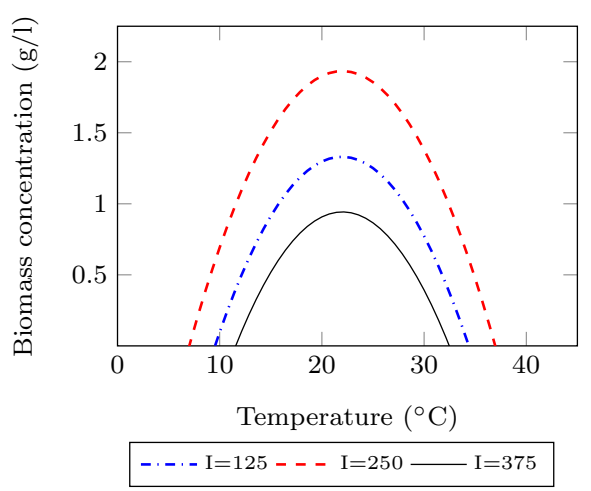

(c) Biomass concentration as a function of temperature and light intensity $\left(\mu \mathrm{E} / \mathrm{m}^{2} / \mathrm{s}\right)$ at $\mathrm{pH}$ of 7.4

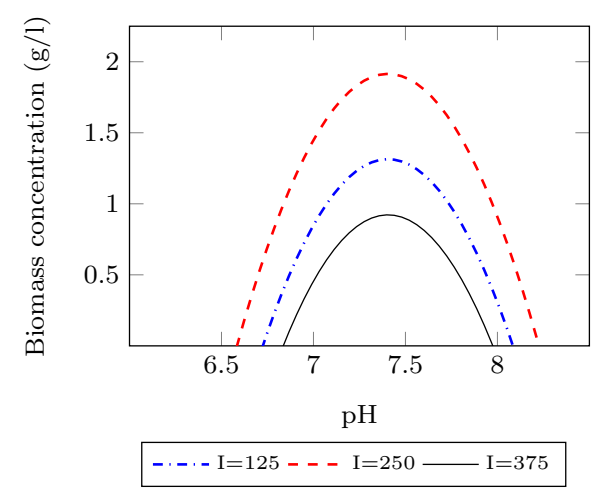

(e) Biomass concentration as a function of $\mathrm{pH}$ and light intensity at temperature of $24^{\circ} \mathrm{C}$

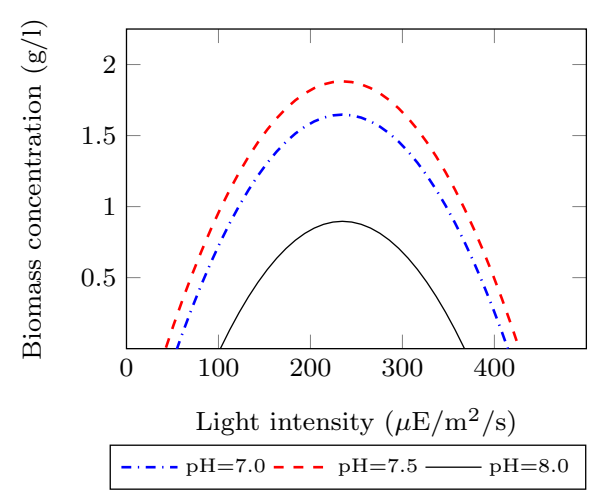

(b) Biomass concentration as a function of light intensity and $\mathrm{pH}$ at $24^{\circ}$

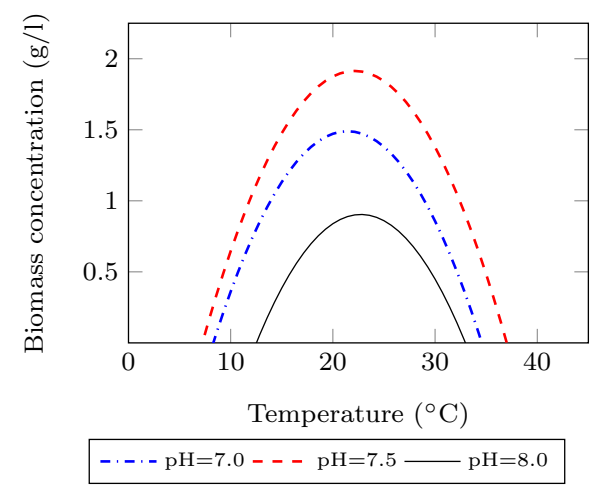

(d) Biomass concentration as a function of temperature and $\mathrm{pH}$ at light intensity of $240 \mu \mathrm{Em}^{-2} \mathrm{~s}^{-1}$

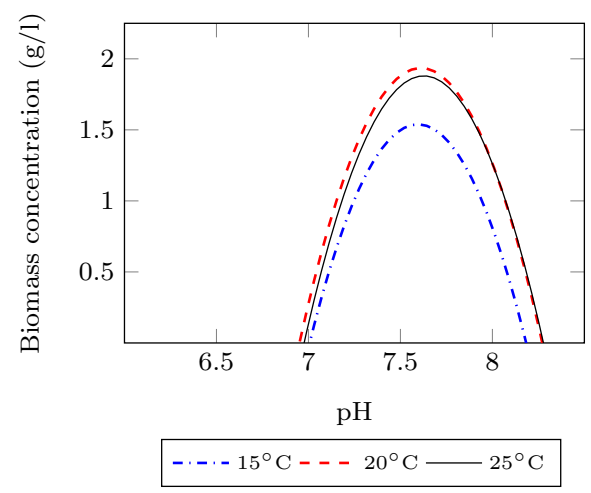

(f) Biomass concentration as a function of $\mathrm{pH}$ and temperature at light intensity of $240 \mu \mathrm{Em}^{-2} \mathrm{~s}^{-1}$

Figure 2: Biomass concentration as a function of environmental growth parameters 


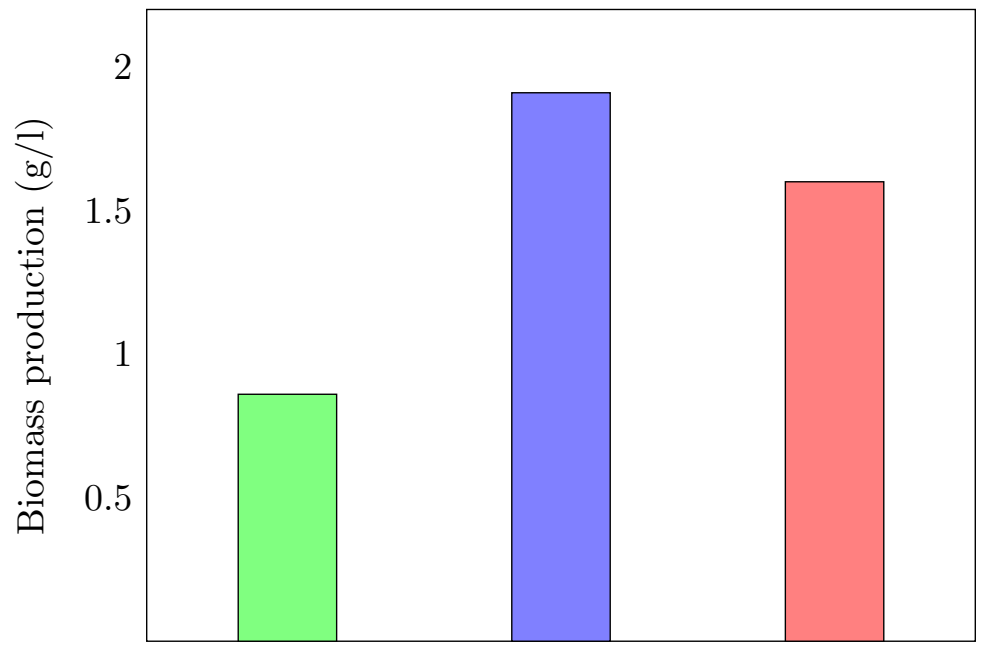

$\square$ Bold $\square$ modified Bold $\square$ wastewater

Figure 3: Algal biomass productions in different media over a 10-day growth period at the optimum environmental growth condition 


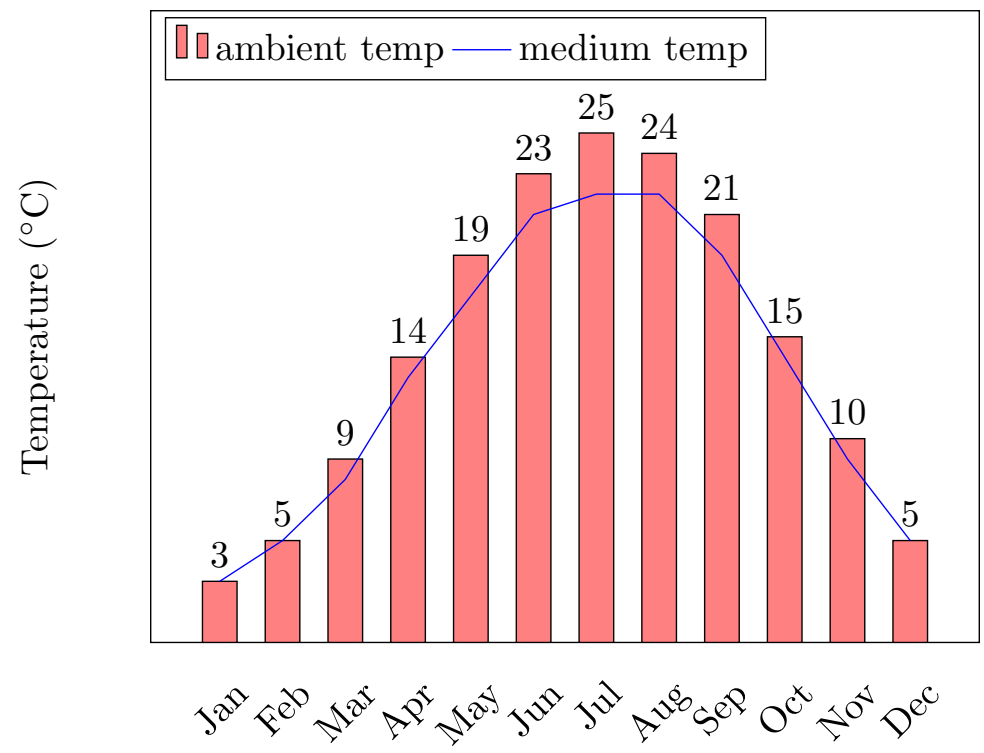

Figure 4: Comparison of average daily ambient temperature and medium temperature $\left({ }^{\circ} \mathrm{C}\right)$ 


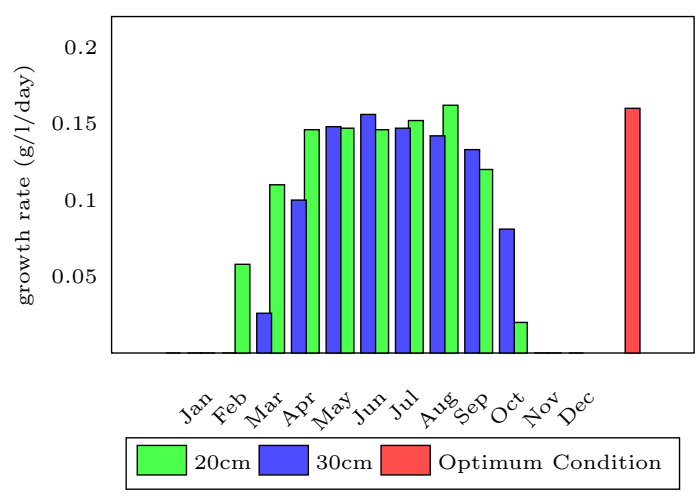

(a) harvesting cell density of $0.1 \mathrm{~g} / \mathrm{l}$

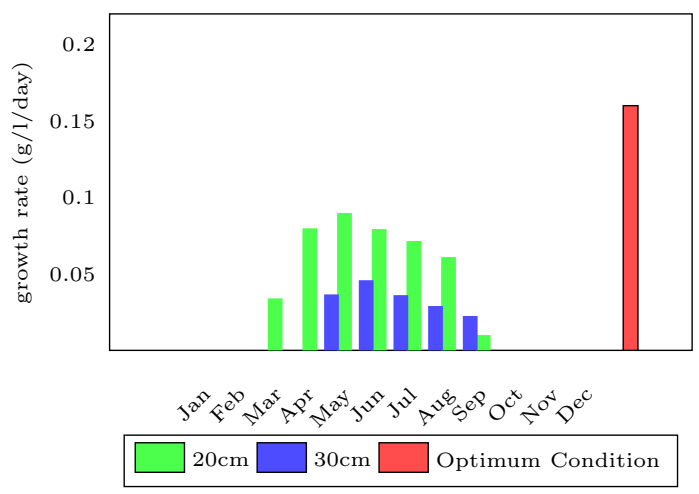

(c) harvesting cell density of $0.3 \mathrm{~g} / \mathrm{l}$

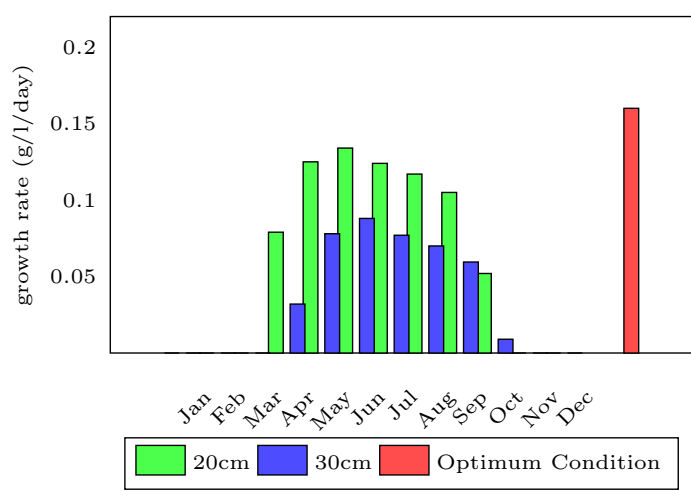

(b) harvesting cell density of $0.2 \mathrm{~g} / \mathrm{l}$

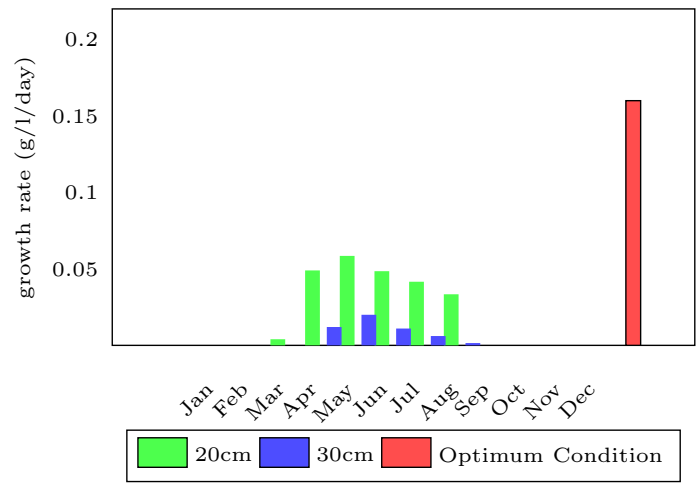

(d) harvesting cell density of $0.4 \mathrm{~g} / \mathrm{l}$

Figure 5: The growth rate of C.vulgaris in swine wastewater 

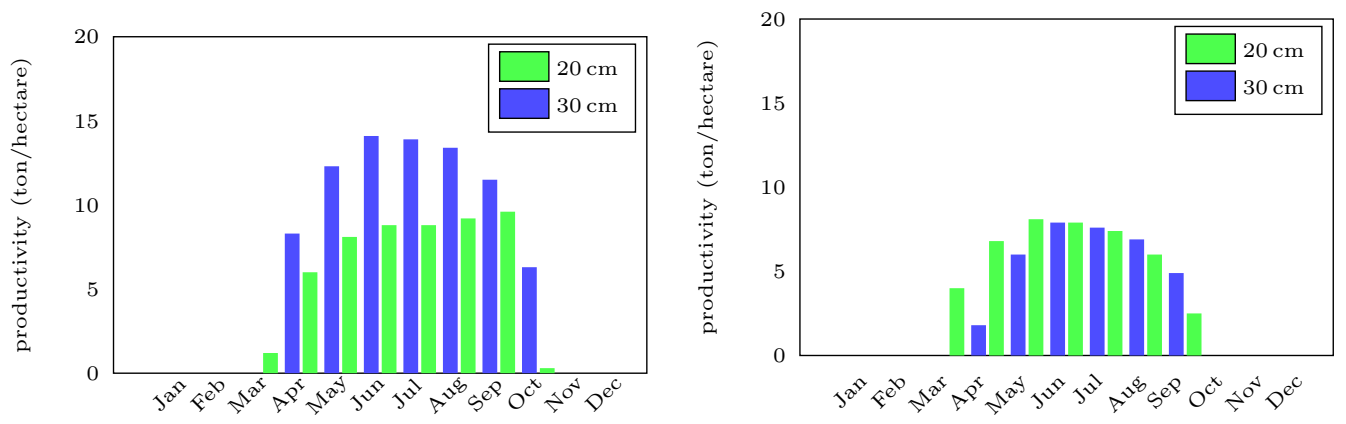

(a) harvesting cell density of $0.1 \mathrm{~g} / \mathrm{l}$

(b) harvesting cell density of $0.2 \mathrm{~g} / \mathrm{l}$
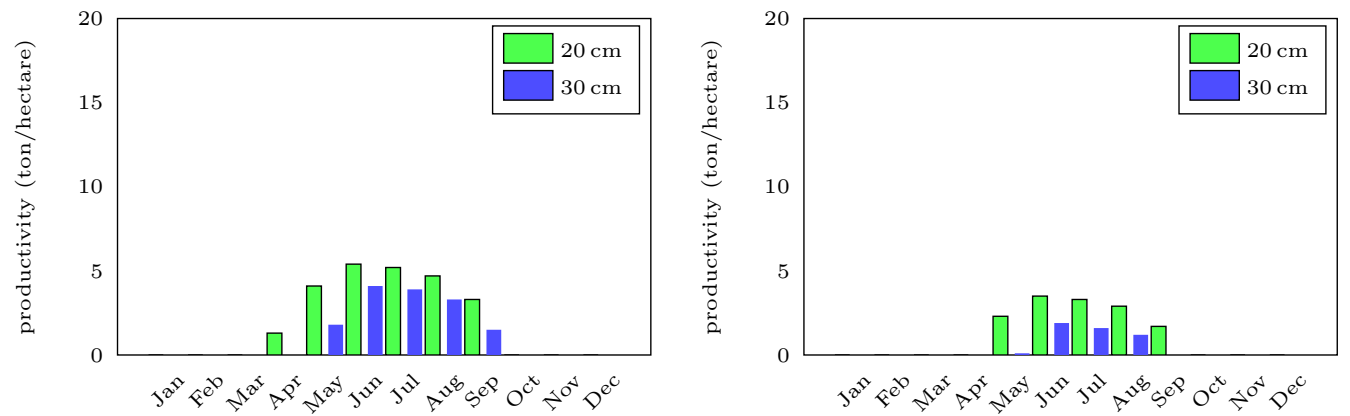

(c) harvesting cell density of $0.3 \mathrm{~g} / \mathrm{l}$

(d) harvesting cell density of $0.4 \mathrm{~g} / \mathrm{l}$

Figure 6: Monthly productivity for one hectare surface area 
Table 1: Characteristics of the swine wastewater

\begin{tabular}{lcl}
\hline Component & Concentration (ppm) & Reference \\
\hline \hline $\mathrm{NH}_{3}-\mathrm{N}$ & 22 & \\
$\mathrm{NO}_{3}-\mathrm{N}$ & 80 & \\
$\mathrm{PO}_{4}-\mathrm{P}$ & 82 & \\
$\mathrm{Fe}$ & 2.4 & {$[19]$} \\
$\mathrm{Cu}$ & 0.4 & {$[19]$} \\
sulfate & 240 & {$[19]$} \\
\hline
\end{tabular}


Table 2: Independent variables and levels used for response surface design

\begin{tabular}{lcccccc}
\hline \multirow{2}{*}{ Independent variables } & \multirow{2}{*}{ Symbols } & \multicolumn{5}{c}{ Levels } \\
\cline { 3 - 7 } & & -1.68 & -1 & 0 & 1 & 1.68 \\
\hline Temperature $\left({ }^{\circ} \mathrm{C}\right)$ & $\mathrm{x}_{1}$ & 10 & 16 & 24 & 32 & 38 \\
Light intensity $\left(\mu E / m^{2} . s\right)$ & $\mathrm{x}_{2}$ & 40 & 120 & 240 & 350 & 430 \\
$\mathrm{pH}$ & $\mathrm{x}_{3}$ & 6.8 & 7.1 & 7.4 & 7.7 & 8.0 \\
\hline
\end{tabular}


Table 3: Experimental and predicted algal biomass concentration over a 10-day growth period

\begin{tabular}{|c|c|c|c|c|c|c|c|c|}
\hline \multirow[t]{2}{*}{ Experiment } & \multicolumn{3}{|c|}{ Coded independent variable levels } & \multicolumn{3}{|c|}{ Actual values of variables } & \multicolumn{2}{|c|}{ Biomass concentration $(\mathrm{g} / \mathrm{l})$} \\
\hline & $\mathrm{x}_{1}$ & $\mathbf{x}_{2}$ & $\mathrm{x}_{3}$ & Temperature $\left({ }^{\circ} \mathbf{C}\right)$ & Light intensity $\mu E / m^{2} s$ & $\mathrm{pH}$ & Experimental & Predicted \\
\hline 1 & -1 & -1 & -1 & 16 & 120 & 7.1 & 0.80 & 0.76 \\
\hline 2 & +1 & -1 & -1 & 32 & 120 & 7.1 & 0.08 & 0.08 \\
\hline 3 & -1 & +1 & -1 & 16 & 350 & 7.1 & 0.84 & 0.74 \\
\hline 4 & +1 & +1 & -1 & 32 & 350 & 7.1 & 0.01 & 0.08 \\
\hline 5 & -1 & -1 & +1 & 16 & 120 & 7.7 & 0.72 & 0.664 \\
\hline 6 & +1 & -1 & +1 & 32 & 120 & 7.7 & 0.095 & 0.20 \\
\hline 7 & -1 & +1 & +1 & 16 & 350 & 7.7 & 0.64 & 0.65 \\
\hline 8 & +1 & +1 & +1 & 32 & 350 & 7.7 & 0.15 & 0.20 \\
\hline 9 & -1.68 & 0 & 0 & 10 & 240 & 7.4 & 0.7 & 0.70 \\
\hline 10 & +1.68 & 0 & 0 & 38 & 240 & 7.4 & 0.01 & -0.27 \\
\hline 11 & 0 & -1.68 & 0 & 24 & 40 & 7.4 & 0.014 & -0.02 \\
\hline 12 & 0 & +1.68 & 0 & 24 & 430 & 7.4 & 0.01 & -0.03 \\
\hline 13 & 0 & 0 & -1.68 & 24 & 240 & 6.8 & 1.13 & 0.87 \\
\hline 14 & 0 & 0 & +1.68 & 24 & 240 & 8.0 & 1.26 & 0.89 \\
\hline 15 & 0 & 0 & 0 & 24 & 240 & 7.4 & 1.92 & 1.91 \\
\hline 16 & 0 & 0 & 0 & 24 & 240 & 7.4 & 1.9 & 1.91 \\
\hline 17 & 0 & 0 & 0 & 24 & 240 & 7.4 & 1.94 & 1.91 \\
\hline 18 & 0 & 0 & 0 & 24 & 240 & 7.4 & 1.85 & 1.91 \\
\hline 19 & 0 & 0 & 0 & 24 & 240 & 7.4 & 1.85 & 1.91 \\
\hline 20 & 0 & 0 & 0 & 24 & 240 & 7.4 & 1.93 & 1.91 \\
\hline
\end{tabular}


Table 4: ANOVA for the fitted quadratic polynomial model for optimization of microalgae biomass concentration

\begin{tabular}{|c|c|c|c|c|c|}
\hline Source & $\begin{array}{l}\text { Sum of } \\
\text { squares }\end{array}$ & $\begin{array}{l}\text { Degree } \\
\text { of free- } \\
\text { dom }\end{array}$ & Mean square & F-value & $\begin{array}{l}\text { P-value } \\
(\text { prob }>F)\end{array}$ \\
\hline Model & 13.97 & 9 & 1.55 & 89.23 & $<0.0001$ (significant) \\
\hline$x_{1}$ (Temperature) & 1.07 & 1 & 1.0 & 61.53 & $<0.0001$ \\
\hline$x_{2}$ (Light intensity) & $2.61 \mathrm{E}-4$ & 1 & $2.61 \mathrm{E}-4$ & 0.015 & 0.9049 \\
\hline$x_{3}(\mathrm{pH})$ & $6.69 \mathrm{E}-4$ & 1 & $6.69 \mathrm{E}-4$ & 0.038 & 0.8484 \\
\hline$x_{1} x_{2}$ & $9.11 \mathrm{E}-5$ & 1 & $9.11 \mathrm{E}-5$ & $5.23 \mathrm{E}-3$ & 0.9437 \\
\hline$x_{1} x_{3}$ & 0.024 & 1 & 0.024 & 1.37 & 0.2666 \\
\hline$x_{2} x_{3}$ & $6.12 \mathrm{E}-6$ & 1 & $6.12 \mathrm{E}-6$ & $3.52 \mathrm{E}-4$ & 0.9854 \\
\hline$x_{1}^{2}$ & 5.55 & 1 & 5.55 & 319.04 & $<0.0001$ \\
\hline$x_{2}^{\frac{1}{2}}$ & 7.93 & 1 & 7.93 & 455.91 & $<0.0001$ \\
\hline$x_{3}^{2}$ & 1.51 & 1 & 1.51 & 86.74 & $<0.0001$ \\
\hline Residual & 0.17 & 10 & 0.17 & & \\
\hline Lack of fit & 0.072 & 5 & 0.072 & 0.7 & 0.6474 (not significant) \\
\hline Pure error & 0.10 & 5 & 0.02 & & \\
\hline $\begin{array}{l}\text { cor Total } \\
\mathrm{R}^{2}=.9877\end{array}$ & 14.14 & 19 & & & \\
\hline
\end{tabular}

